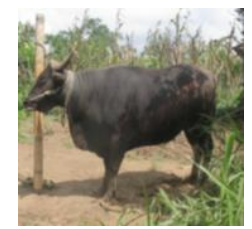

Jurmal FADET UNUD

Editor-Reviewer Article;: A.A. Pt. Putra Wibawa \& $\mathcal{N}$ i Putu Mariani

\title{
PENGARUH SUPLEMENTASI ASAM AMINO ESENSIAL PADA PAKAN BERBASIS JAGUNG-POLLARD TERHADAP DIMENSI TUBUH BABI BALI
}

\author{
Lewis, I K. L, I. K. Sumadi, dan A. A. P. P. Wibawa \\ PS. Peternakan, Fakultas Peternakan, Universitas Udayana, Jl. P.B. Sudirman, Denpasar \\ E-mail: komanglennox@student.unud.ac.id, Telepon: +6287760052849
}

\begin{abstract}
ABSTRAK
Penelitian ini bertujuan untuk mengetahui pengaruh suplementasi asam amino lisin, metionin, triptofan pada ransum berbasis jagung-pollard terhadap dimensi tubuh babi bali jantan. Penelitian dilaksanakan selama 12 minggu di Jalan kresna, Banjar Batuparas, Desa Padang Sambian Kaja. Rancangan yang digunakan adalah Rancangan Acak Lengkap (RAL) dengan 3 perlakuan. Perlakuan P0 (50\% jangung kuning $+49 \%$ pollar $+0,5 \% \mathrm{NaCl}$ dan + $0,5 \%$ campuran mineral), P1 (50\% jangung kuning $+49 \%$ pollar $+0,5 \% \mathrm{NaCl}+0,5 \%$ campuran mineral + asam amino lisin + metionin + triptofan), P2 (Ransum rekomendasi dengan $\mathrm{ME} / \mathrm{CP}$ ratio $=2800 \mathrm{kkal} / \mathrm{kg} / 16 \%$ ) yang di ulang sebanyak 4 kali, setiap ulangan terdiri dari 1 ekor ternak, sehingga menggunakan 12 ekor babi bali jantan. Variabel yang diamati adalah dimensi tubuh babi bali jantan yaitu lingkar dada, lingkar perut, tinggi pundak, tinggi punggung, tinggi pinggul dan panjang badan. Hasil penelitian menunjukkan suplementasi asam amino lisin, metionin,dan triptofan pada dimensi tubuh babi bali jantan memiliki pengaruh yang berbeda nyata $(\mathrm{P}<0,05)$ pada variabel yang meliputi lingkar dada, panjang badan, tinggi pundak, lingkar perut, tinggi punggung, tinggi pinggul. Berdasarkan hasil penelitian dapat di simpulkan bahwa penambahan asam amino lisin, metionin dan triptofan pada ransum berbasis jagung pollar dapat meningkatkan dimensi tubuh babi bali jantan yang meliputi lingkar dada, panjang badan, tinggi pundak, lingkar perut, tinggi punggung, dan tinggi pinggul.
\end{abstract}

Kata Kunci: Babi bali jantan, dimensi tubuh, suplementasi asam amino (lisin, metionin,dan triptofan)

\section{THE INFLUENCE OF ESSENTIAL AMINO ACIDS ON POLLARD-CORN FEED BASE TO THE BODY DIMENSIONS OF THE BALI PIG}

\begin{abstract}
This research is intend to find out the influence of the lysine, methionine, and the tryptophan amino acid supplementation on the pollard corn base ration to the dimension of the male Bali pig. This research was held for 12 weeks in Jalan Kresna, Banjar Batuparas, Desa
\end{abstract}


Padang Sambian Kaja. The design that is used is the completely randomized design with 3 different handlings, they are P0 ( $50 \%$ yellow corn $+49 \%$ pollard $+0,5 \% \mathrm{NaCl}$ and $+0,5 \%$ mineral mixture ), PI ( $50 \%$ yellow corn $+49 \%$ pollard $+0,5 \% \mathrm{NaCl}+0,5 \%$ mineral mixture + lysine amino acid + methionine + tryptophan ), P2 ( Recommended ration with the ME/CP ratio $=2800 \mathrm{kcal} / \mathrm{kg} / 16 \%$ ) which is repeated for 4 times, and each repetition consist of 1 livestock, so it used 12 male Bali pigs. The variable that was being observed is the dimension of the bali pig body, which are the chest size, stomach circumference, shoulder height, back height, hip height, and the body length. The result of the research shows that the supplementation of the lysine, methionine, and tryptophan amino acid on the dimension of the bali pig have a significant influence $(\mathrm{P}<0,05)$ on the variables that are the chest size, body length, shoulder height, stomach circumference, back height, and the hip height. Based on the result of the research we can conclude that the addition of the lysine, methionine, tryptophan amino acid on the pollard corn base ration can increase the dimension of bali pig body which are the chest size, body length, shoulder height, stomach circumference, back height, and the hip height.

Keywords : bali pig, body dimension, (lysine amino acid, methionine, and the tryptophan) supplementation.

\section{PENDAHULUAN}

Babi bali merupakan babi endemik di Bali yang memiliki peluang tinggi di daerah Bali yang digunakan untuk konsumsi dan untuk upacara keagamaan. Babi bali merupakan ternak lokal yang sudah cukup dikenali oleh peternak, ciri-ciri fisik babi bali yang mudah untuk dikenali masyarakat dari warna bulunya yang hitam dan terasa kasar, bagian punggung yang melengkung, dan telinga yang tegak. Budaarsa (2012) babi bali memiliki keunggulan yaitu mampu mengonsumsi pakan limbah dan lebih hemat terhadap air serta mampu mengonversi pakan yang diberikan dan merubahnya menjadi lemak dan daging. Menurut Budaarsa et al. (2016) pada pemeliharaan babi bali diperlukan waktu 12 bulan untuk mencapai berat badan $80 \mathrm{~kg}$, sedangkan babi ras impor hanya 5-6 bulan. sedangkan kelebihan babi bali adalah babi yang tahan menderita,lebih hemat terhadap air, masih mampu bertahan hidup walau diberi makan seadanya, sehingga sangat cocok dipelihara di daerah yang kering.

Dimensi tubuh merupakan faktor yang erat hubungannya dengan penampilan dan sifat produksi seekor ternak yang dapat digunakan untuk menduga berat badan ternak (Santosa,1991). Sampurna et al. (2013) pertumbuhan dimensi tubuh ternak pada saat tumbuh cepat biasanya mengikuti fungsieksponensial dengan laju pertumbuhan yang berbeda-beda antara dimensi tubuh yang satudengan dimensi tubuh yang lainnya.Ransum pada dasarnya ditujukan untuk memenuhi kebutuhan energi bagi ternak. Menurut Siregar (1994) ransum 
adalah campuran dari dua atau lebih bahan pakan yang diberikan untuk seekor ternak selama sehari yang memiliki fungsi, diantaranya meliputi: hidup pokok, produksi dan reproduksi. Barnes et al. (1995) menyatakan bahwa kualitas protein dalam bahan pakan dinyatakan tinggi atau rendah bergantung pada kandungan asam amino esensial dalam bahan pakan tersebut.

Asam amino merupakan komponen utama penyusunan protein, dan dibagi dalam dua bagian kelompok yaitu asam amino esensial dan non-esensial Menurut Cheeke (2005) asam amino esensial harus ada di dalam bahan ransum karena tidak dapat disintesis dalam tubuh ternak. Menurut Sundari et al. (2004) asam amino lisin merupakan asam amino pembatas pertama pada ransum babi, Lisin dapat meningkatkan pembentukan daging yang memerlukan banyak energi, sehingga retensi energi dalam bentuk lemak menurun.

Sigit (1995) menyatakan bahwa asam amino metionin juga merupakan salah satu kerangka pembentuk protein tubuh. Prawirokusumo et al.(1987) asam amino metionin sangat diperlukan untuk kecepatan pertumbuhan dan hidup pokok semua hewan. Salah satu akibat bila terjadi kekurangan asam amino metionin adalah lambatnya laju pertumbuhan.Triptofan adalah salah satu asam amino esensial yang biasanya ditemukan dalam bahan pakan, namun jumlahnya masih terbatas. Menurut Sumadi et al., (2018) sumber triptofan banyak terdapat pada biji-bijian, kacang-kacangan, dan bungkil kacang kedelai yang sangat kaya akan kandungan triptofan. Menurut NRC (2012) kebutuhan asam amino triptofan dalam pakan babi fase stater dengan berat badan $10-20 \mathrm{~kg}$ adalah 0,21\%. Yuliyanti. (2018) menyatakan bahwa pemberian ransum dengan suplementasi campuran lisin, metionin dan kolin sebanyak 0,5\% dan $1 \%$ pada babi bali jantan belum memberikan hasil yang berbeda terhadap dimensi tubuh yang meliputi tinggi pundak, tinggi punggung, tinggi pinggul, lingkar dada, lingkar perut, panjang badan. Pemberian suplementasi campuran lisin, metionin, dan triptofan pada ransum diharapkan dapat meningkatkan pertumbuhan dimensi tubuh babi bali.

\section{MATERI DAN METODE}

\section{Ternak babi}

Babi yang digunakan dalam penelitian ini merupakan babi lokal khas Bali dengan berat badan 11,41 $\pm 0,91 \mathrm{~kg}$, sebanyak 12 ekor. Babi bali jantan lepas sapih dibeli dari pengepul babi bali yang ada di Desa Gerokgak, Kabupaten Buleleng, Bali. 


\section{Kandang dan perlengkapan}

Kandang yang digunaan pada penelitian merupakan kandang individu yang terbuat dari kayu dan bambu dengan atap terpal dengan jumlah 12 unit yang berukuran $1 \mathrm{~m}^{2}$. Tiap perlakuan menggunakan 4 unit kandang. Lantai kandang terbuat dari bambu yang terdapat sekat agar kotoran babi dapat langsung jatuh ketanah. Di dalam kandang terdapat tempat pakan dan air minum yang terbuat dari plastik.

\section{Alat penelitian}

Alat yang digunakan adalah pita ukur, penggaris, dan timbangan. Pita ukur untuk mengukur lingkar dada, lingkar perut, panjang badan dan penggaris digunakan untuk mengukur tinggi pundak, tinggi punggung, dan tinggi pinggul.

\section{Ransum penelitian}

Ransum adalah campuran beberapa bahan pakan yang disusun sesuai kebutuhan hidup dan poduksi dari ternak. Ransum yang digunakan dalam penelitian ini yaitu campuran jagung kuning, pollard, mineral 10 dan $\mathrm{NaCl}$ yang diberikan tambahan campuran lisin, metionin, dan triptofan. Komposisi bahan penyusun ransum, kandungan campuran lisin, metionin dan triptofan, kandungan zat makanan pada ransum penelitian disajikan pada Tabel 1 dan 2 .

Tabel 1. Komposisi bahan penyusun ransum

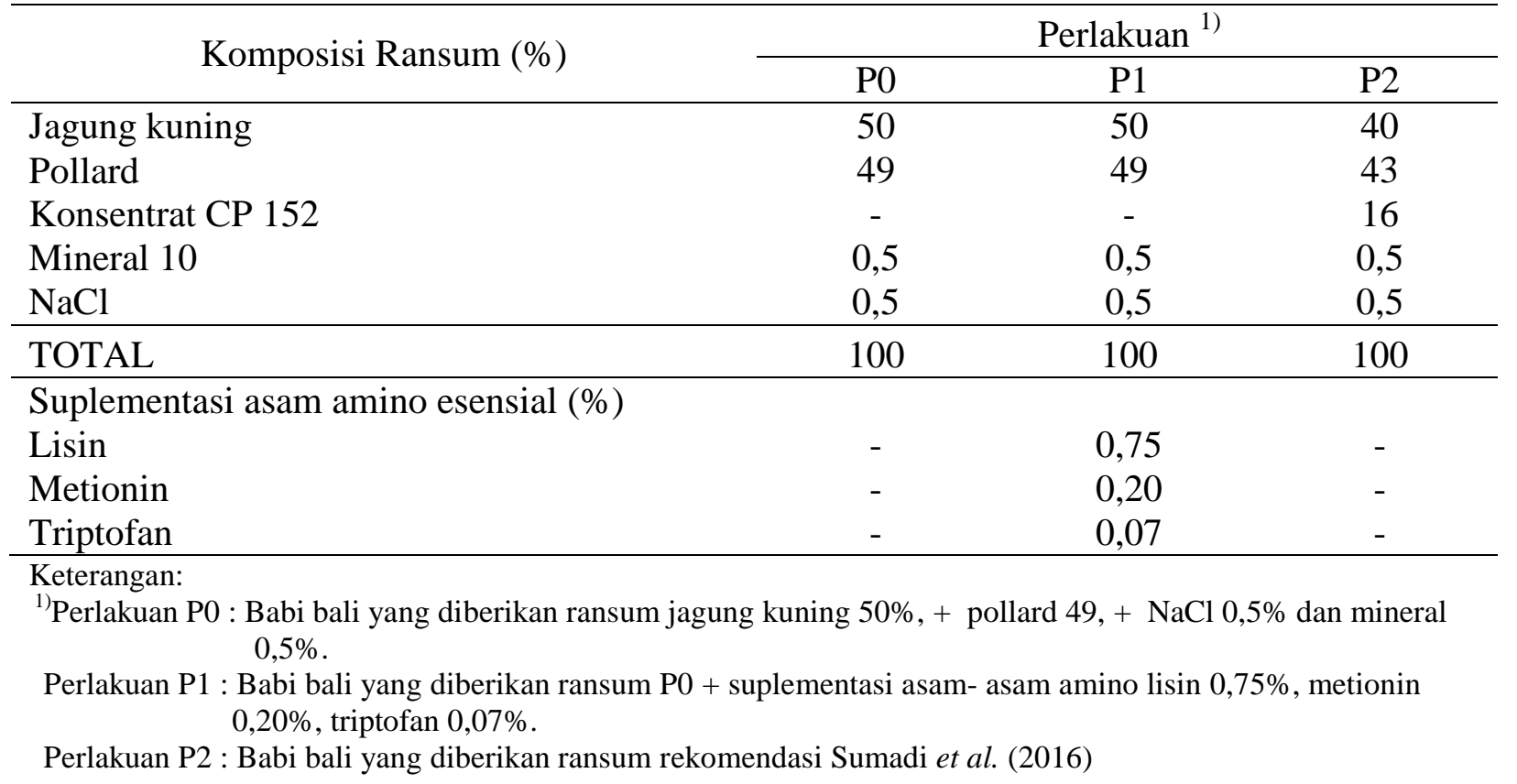


Tabel 2. Komposisi nutrien ransum

\begin{tabular}{|c|c|c|c|c|}
\hline \multirow{2}{*}{ Kandungan Nutrien (\%) } & \multicolumn{3}{|c|}{ Perlakuan } & \multirow{2}{*}{ Standar $^{2)}$} \\
\hline & P0 & P1 & $\mathrm{P} 2^{1)}$ & \\
\hline $\mathrm{ME}(\mathrm{Kkal} / \mathrm{kg})^{2)}$ & 2825 & 2825 & 2794,25 & 2800 \\
\hline Protein $^{2)}$ & 11,84 & 11,84 & 16,15 & 16 \\
\hline Lisin & 0,42 & 1,17 & - & 1,15 \\
\hline Metionin & 0,46 & 0,66 & - & 0,65 \\
\hline Triptofan & 0,14 & 0,21 & - & 0,21 \\
\hline $\begin{array}{r}\text { Keterangan: } \\
\text { 1) } \mathrm{S}\end{array}$ & & & & \\
\hline
\end{tabular}

\section{Tempat dan waktu penelitian}

Penelitian dilaksanakan di Jalan kresna, Dusun Batuparas, Desa Padangsambian Kaja, Kecamatan Denpasar Barat, Kabupaten Denpasar. Penelitian dilaksanakan selama 12 minggu di mulai dari tanggal 1 Juli - 30 september 2019, untuk pengambilan data pengukuran dimensi tubuh babi di lakukan setiap 1 bulan sekali dan 2 minggu untuk penyesuaian babi bali terhadap pakan.

\section{Rancangan penelitian}

Penelitian ini menggunakan rancangan acak lengkap (RAL) yang terdiri atas tiga perlakuan dan empat ulangan. Ketiga perlakuan yang dicobakan kepada babi bali jantan jantan lepas sapih terdiri atas:

P0 : Babi bali jantan yang diberikan ransum jagung kuning 50\%, + pollard 49, + $\mathrm{NaCl} 0,5 \%$ dan mineral $0,5 \%$.

P1 : Babi bali jantan yang diberikan ransum P0 + campuran asam-asam amino lisin $0,75 \%$, metionin $0,20 \%$, triptofan $0,07 \%$.

P2 :Babi bali yang diberikan ransum rekomendasi dengan $\mathrm{ME} / \mathrm{CP}$ ratio $=2800$ $\mathrm{kkal} / \mathrm{kg} / 16 \%$ (Sumadi et al., 2016)

\section{Pengacakan babi}

Babi bali jantan lepas sapih sebanyak 12 ekor ditimbang kemudian diberikan nomor dan dicari berat rata-rata yang tidak jauh berbeda. Selanjutnya babi ditempatkan pada tiaptiap kandang secara berurutan sesuai dengan perlakuan.

\section{Pemberian ransum dan air minum}

Ransum yang diberikan berbentuk tepung ("mash"). Pemberian ransum dilakukan dua kali dalam sehari yaitu pada pagi hari pukul 07.30 Wita dan pada sore hari pada pukul 16.30 Wita. Sebelum pemberian ransum, kandang dan tempat pakan dibersihkan terlebih dahulu 
agar kotoran babi tidak mengganggu babi. Air diberikan secara ad libitum atau selalu tesedia untuk ternak.

Variabel Yang Diamati

Pengukuran dimensi tubuh dilakukan setiap 1 bulan sekali. Variabel yang diamati dalam penelitian ini adalah dimensi tubuh luar babi bali jantan menurut (Djagra, 2001) meliputi :

\section{Lingkar dada}

Pengukuran lingkar dada dilakukan ketika ternak babi berada dalam posisi berdiri tegak, dengan posisi keempat kaki sejajar. Lingkar dada diukur dengan cara melingkarkan pita ukur mulai dari titik tertinggi bahu melewati tulang rusuk tepat dibelakang siku kaki depan dan kembali lagi ke titik awal.

\section{Lingkar perut}

Pengukuran lingkar perut dilakukan ketika ternak babi dalam posisi berdiri tegak, dengan posisi keempat kaki sejajar. Lingkar perut diukur dengan cara melingkarkan pita ukur mulai dari titik tertinggi punggung dan melingkarkan melalui perut dan kembali ketitik awal.

\section{Tinggi pundak}

Pengukuran tinggi pundak dilakukan ketika ternak berada pada posisi tegak dengan posisi keempat kaki sejajar. Pengukuran tinggi pundak diukur dari lantai sampai titik tertinggi pundak, melalui persis ditengah-tengah kaki depan.

\section{Tinggi punggung}

Pengukuran tinggi punggung dilkukan pada saat babi dalam posisi tegak dengan posisi kaki keempatnya sejajar. Tinggi punggung diukur dari lantai sampai titik tertinggi punggung, persis dibelakang tulang scapula atau tepatnya pada tulang rusuk keempat.

\section{Tinggi panggul}

Pengukuran tinggi pinggul dilakukan pada saat babi berdiri tegak dan posisi keempat kaki dalam keadaan sejajar. Tinggi pinggul diukur dari lantai sampai titik tertinggi pinggul, persis melalui depan kaki belakang.

\section{Panjang badan}

Pengukuran panjang badan dilakukan pada saat ternak babi dalam posisi berdiri tegak dengan keempat kaki sejajar panjang badan diukur melalui tuberositas humerus sampai tuber ischia pada sisi yang sama menggunakan pita ukur. 
Analisis statistika

Data yang diperoleh dianalisis dengan sidik ragam dan apabila diantara perlakuan terdapat perbedaan nyata $(\mathrm{P} \leq 0,05)$, analisis akan dilanjutkan dengan Uji Jarak Berganda Duncan's (Steel dan Torrie, 1991)

\section{HASIL DAN PEMBAHASAN}

\section{Lingkar dada}

Rataan lingkar dada babi bali jantan yang diberikan ransum jagung kuning 50\%, pollard $49 \%, \mathrm{NaCl} 0,5 \%$ dan mineral $0,5 \%$ (P0), bali bali jantan yang diberikan ransum $\mathrm{P} 0+$ campuran asam-asam amino lisin 0,75\%, metionin 0,20\% dan triptofan 0,07\% (P1), dan babi bali jantan yang diberikan ransum rekomendasi Sumadi et al. (2016) (P2) berturut-turut adalah $65,50 \mathrm{~cm}, 71,00 \mathrm{~cm}$ dan 75,50 $\mathrm{cm}$ ( Tabel 3 ). Lingkar dada babi bali jantan yang mendapatkan perlakuan P0 lebih kecil 7,75\% terhadap perlakuan P1 dan perlakuan P2 lebih besar 6,34\% terhadap perlakuan P1, namun secara statistik perlakuan P2 dan P1 berbeda nyata $(\mathrm{P}<0,05)$ dengan perlakuan $\mathrm{P} 0$.

Tabel 3. Dimensi tubuh babi bali jantan yang di berikan ransum dengan suplemntasi asam amino lisin, metionin, triptofan.

\begin{tabular}{lcccc}
\hline \multirow{2}{*}{ Variabel (cm) } & \multicolumn{3}{c}{ Perlakuan $^{1)}$} & \multirow{2}{*}{ SEM $^{2)}$} \\
\cline { 2 - 4 } & $\mathrm{P} 0$ & $\mathrm{P} 1$ & $\mathrm{P} 2$ & \\
\hline Lingkar Dada & $65,50^{\mathrm{b}}$ & $71,00^{\mathrm{a}}$ & $75,50^{\mathrm{a}}$ & 1,59 \\
Panjang Badan & $56,90^{\mathrm{b}}$ & $63,25^{\mathrm{a}}$ & $67,80^{\mathrm{a}}$ & 1,47 \\
Tinggi Pundak & $38,50^{\mathrm{b}}$ & $42,25^{\mathrm{a}}$ & $46,40^{\mathrm{a}}$ & 1,39 \\
Lingkar Perut & $80,00^{\mathrm{a}}$ & $83,75^{\mathrm{a}}$ & $87,60^{\mathrm{a}}$ & 2,19 \\
Tinggi Pinggul & $4,40^{\mathrm{a}}$ & $45,50^{\mathrm{a}}$ & $48,90^{\mathrm{a}}$ & 1,63 \\
Tinggi Punggung & $36,80^{\mathrm{b}}$ & $40,50^{\mathrm{ab}}$ & $45,00^{\mathrm{a}}$ & 1,49 \\
\hline
\end{tabular}

\section{Keterangan:}

${ }^{1)}$ Perlakuan P0 : Babi bali yang diberikan ransum jagung kuning $50 \%,+$ pollard $49,+\mathrm{NaCl} 0,5 \%$ dan mineral $0,5 \%$.

Perlakuan P1 : Babi bali yang diberikan ransum P0 + suplementasi asam- asam amino lisin 0,75\%, metionin $0,20 \%$, triptofan $0,07 \%$.

Perlakuan P2 : Babi bali yang diberikan ransum rekomendasi Sumadi et al. (2016)

${ }^{2)}$ SEM :"Standar Error of the Treatment Means"

Hasil penelitian P2 lebih besar di bandingkan penelitian Yuliyanti, (2018) bahwa suplementasi asam amino campuran lisin, metionin, kolin dalam ransum dengan level $1 \%$ di dapatkan lingkar dada babi bali sebesar 73,67 $\mathrm{cm}$. Suplementasi asam amino lisin, metionin dan triptofan pada ransum berbasis jagung pollard mampu meningkatkan dimensi tubuh pada variabel lingkar yang diikuti dengan peningkatan berat badan babi bali (Lampiran 7). Sejalan dengan yang tertera dalam U.S. Pork Center of Execellence (2010), asam amino esensial 
berupa lisin dan metionin sangatpenting bagi pertumbuhan babi namun kandungannya masih terbatas pada bahan pakan nabati.

Sundari et al. (2004) menyatakan bahwa lisin mampu meningkatkan terbentuknya karnitin, sehingga lemak tubuh yangmengalami $\beta$-oksidasi semakin meningkat dan mengakibatkan kadar lemak dan kolesterol rendah sehingga dapat meningkatkan pembentukan daging. Sulastri et al. ( 2018) metionin merupakan asam amino yang mampu menghasilkan glukosa pada proses metabolisme menurunkan jumlah energi bruto yang dibuangmelalui feses dan meningkatkan energi bruto yang diserap dan dicerna untukpertumbuhan lebih baik. Pierpoali et al, (1995) menyatakan bahawa triptofan merupakan prekursor serotonin dan serotonin dapat dirubah menjadi melatonin serotonin maupun melatonin mampu meemberikan efek tenang pada otak.

\section{Panjang badan}

Hasil penelitian menunjukan bahwa rataan panjang badan babi bali jantan pada perlakuan P1 adalah 63,25 cm. Panjang badan babi bali jantan yang mendapatkan perlakuan P0 lebih kecil 10,08\% terhadap perlakuan P1 dan perlakuan P2 lebih beasr 7,11\% terhadap perlakuan $\mathrm{P} 1$, namun secara statistik perlakuan $\mathrm{P} 2$ dan $\mathrm{P} 1$ berbeda nyata $(\mathrm{P}<0,05)$ dengan perlakuan P0. Hasil penelitian P2 lebih besar dibandingkan penelitian Yuliyanti, (2018) bahwa suplementasi asam amino campuran lisin, metionin, kolin dalam ransum dengan level $1 \%$ di dapatkan panjang badan babi bali sebesar $66,00 \mathrm{~cm}$.

Peningkatan panjang badan babi di pengaruhi oleh kecukupan nutrien dalam ransum sehingga variabel panjang badan bertumbuh dengan optimal. Sejalan dengan pernyataan Setiawan et al.,2014 panjang badan ternak berkaitan erat dengan tingkat kecukupan nutrien selama masa pertumbuhan, makapertumbuhan tulang belakang ternak tersebut akan lebih baik daripada ternak yangmengalami defisiensi nutrien. NRC, (2012) menyatakan bahwa terdapat dua macam asam amino pembatas masing-masing adalah asam amino lisin, metionin (juga terkadang triptofan), asam amino pembatas tersebut memang ketersediaanya terbatas pada bahan pakan nabati (jangung, pollard) dan asam amino pembatas sangat di perlukan untuk memenuhi kebutuhan babi pada fase pertumbuhaban.

\section{Tinggi pundak}

Hasil penelitian menunjukan bahwa rataan panjang badan babi bali jantan pada perlakuan P1 adalah 42,25 cm. Tinggi pundak babi bali jantan yang mendapatkan perlakuan P0 lebih kecil 8,88\% terhadap perlakuan P1 dan perlakuan P2 lebih besar 9,76\% terhadap 
perlakuan $\mathrm{P} 1$, namun secara statistik perlakuan $\mathrm{P} 2$ dan $\mathrm{P} 1$ berbeda nyata $(\mathrm{P}<0,05)$ dengan perlakuan P0. Hasil penelitian P2 lebih besar dibandingkan penelitian Yuliyanti, (2018) bahwa suplementasi asam amino campuran lisin, metionin, kolin dalam ransum dengan level $1 \%$ didapatkan tinggi pundak babi bali sebesar $43,67 \mathrm{~cm}$.

Suplementasi asam amino lisin, metionin dan triptofan pada ransum berbasis jagung pollard mampu meningkatkan tinggi pundak babi bali jantan, namun tidak sebaik perlakuan P2. Kalsium $(\mathrm{Ca})$ dan posfor $(\mathrm{P})$ memiliki peranan yang sangat penting dalam pertumbuhan, perkembangan sistem tulang dan beberapa fungsi fisiologis pada tubuh hewan maka pertumbuhan tulang bagian kaki depan tumbuh secara teratur. Sejalan dengan pendapat Budaarsa et al. (2007) menyatakan pembentukan tulang di pengaruhi oleh dua mineral yang penting yaitu mineral fosfor dan kalsium yang ada didalam ransum. Soeparno (2009) menyatakan bahwa tulang tumbuh secara terus-menerus dengan kadar laju pertumbuhan yang relatif lambat. Seperti yang dikemukakan Tillman et al., (1998) pertumbuhan pada umumnya mempunyai tahap cepat dan lambat, tahap cepat terjadi sebelum dewasa kelamin dan tahap lambat pada fase awal dan saat kedewasaan tubuh telah tercapai.

\section{Tinggi pinggul}

Hasil penelitian menunjukan bahwa rataan tinggi pinggul babi bali jantan pada perlakuan P1 adalah 45,50 cm. Tinggi pinggul babi bali jantan yang mendapatkan perlakuan P0 lebih kecil 6,87\% terhadap perlakuan P1 dan perlakuan P2 lebih besar 7,42\% terhadap perlakuan $\mathrm{P} 1$, namun secara statistik perlakuan berbeda tidak nyata $(\mathrm{P}>0,05)$. Hasil penelitian P1 dan P2 lebih besar dibandingkan penelitian Yuliyanti, (2018) bahwa suplementasi asam amino campuran lisin, metionin, kolin dalam ransum dengan level 1\% di dapatkan tinggi pinggul babi bali sebesar $45,33 \mathrm{~cm}$.

Pertumbuhan tinggi pinggul termasuk ke dalam pertumbuhan masak lambat yang artinya pertumbuhannya masih berlanjut meskipun pertumbuhan tubuh bagian depan telah tumbuh secara maksimal. Menurut Setiawan et al. (2014) pada dasarnya semua bagian dari tubuh hewan tumbuh secara teratur, namun tidak tumbuh dalam satu kesatuan karena berbagai jaringan tubuh tumbuh dengan laju yang berbeda dari lahir sampai dewasa. Sejalan dengan pernyataan Djagra, (2001) menyatkan bahwa pertumbuhan diawali pada bagian anggota tubuh depan dan kemudian diikuti pada anggota bagian belakang, sehingga tinggi bahu akan lebih rendah dari tinggi pinggul yang mengakibatkan penampilan babi agak condong ke depan. 


\section{Lingkar perut}

Hasil penelitian menunjukan bahwa rataan panjang badan babi bali jantan pada perlakuan P1 adalah $83,75 \mathrm{~cm}$. Lingkar perut babi bali jantan yang mendapatkan perlakuan P0 lebih kecil 4,48\% terhadap perlakuan P1 dan perlakuan P2 lebih besar 4,63\% terhadap perlakuan $\mathrm{P} 1$, namun secara statistik perlakuan berbeda tidak nyata $(\mathrm{P}>0,05)$. Hasil penelitian P2 lebih besar dibandingkan penelitian Yuliyanti, (2018) bahwa suplementasi asam amino campuran lisin, metionin, kolin dalam ransum dengan level 1\% di dapatkan lingkar perut babi bali sebesar $86,00 \mathrm{~cm}$.

Babi bali masih pada fase pertumbuhan dini, dimana otot atau daging dan lemak pada babi belum tumbuh secara optimal. Menurut Sampurna, (2013) perbedaan kecepatan pertumbuhan disebabkan oleh perbedaan fungsi dan komponen penyusunnya, bagian tubuh yang berfungsi lebih awal atau komponen penyusunnya sebagian besar dari tulang akan tumbuh lebih dulu dibandingkan dengan yang berfungsi lebih belakang, atau komponen penyusunnya terdiri dari otot dan lemak.

\section{Tinggi punggung}

Hasil penelitian menunjukan bahwa rataan tinggi punggung babi bali jantan pada perlakuan P1 adalah 40,50 $\mathrm{cm}$. Tinggi punggung babi bali jantan yang mendapatkan perlakuan P0 lebih kecil 9,26\% terhadap perlakuan P1 dan perlakuan P2 lebih besar 11,11\% terhadap perlakuan $\mathrm{P} 1$, namun secara statistik perlakuan berbeda tidak nyata $(\mathrm{P}>0,05)$. Hasil penelitian P2 lebih besar dibandingkan penelitian Yuliyanti, (2018) bahwa suplementasi asam amino campuran lisin, metionin, kolin dalam ransum dengan level 1\% didapatkan tinggi punggung babi bali sebesar $42,00 \mathrm{~cm}$.

Pada variabel tinggi punggung babi bali masih dalam fase pertumbuhan dini, dimana pertumbuhan tulang pada babi masih berlangsung sehingga pada variabel tinggi punggung mengalami perbedaan pertumbuhan. Seperti yang di kemukakan Tillman et al., (1998) setiap komponen tubuh memiliki laju pertumbuhan yang berbeda-beda, pertumbuhan pada umumnya mempunyai tahap cepat dan lambat tahap cepat terjadi sebelum dewasa kelamin dan tahap lambat pada fase awal dan saat kedewasaan tubuh telah tercapai. Soeparno, (2009) menyatakan bahwa tulang tumbuh secara terus-menerus dengan kadar laju pertumbuhan yang relatif lambat. 


\section{SIMPULAN DAN SARAN}

Berdasarkan hasil penelitian ini dapat di simpulkan bahwa penambahan asam amino lisin $0,75 \%$, metionin $0,20 \%$ dan triptofan $0,07 \%$ pada ransum berbasis jagung-pollard secara umum dapat meningkatkan dimensi tubuh babi bali jantan yang meliputi lingkar dada, panjang badan, tinggi pundak, lingkar perut, tinggi punggung, dan tinggi pinggul. Berdasarkan hasil penelitian ini dapat di sarankan kepada peternak babi bali dengan suplementasi asam amino esensial ( lisin, metionin, triptofan) dalam pakan berbasis jagung kuning dan pollard dapat meningkatkan dimensi tubuh babi bali janta.

\section{UCAPAN TERIMAKASIH}

Penulis mengucapkan terima kasih kepada Rektor Universitas Udayana Prof. Dr. dr. A. A. Raka Sudewi, Sp.S (K) dan Dekan Fakultas Peternakan Universitas Udayana Dr. Ir. I Nyoman Tirta Ariana, MS yang telah memberikan kesempatan dan fasilitas kepada penulis selama menjalani perkuliahan di Fakultas Peternakan, Universitas Udayana.

\section{DAFTAR FUSTAKA}

Budaarsa, K, Siagian P.H, dan Kartiarso. 2007. Penggunaan rumput laut dan sekam padi sebagai sumber serat dalam ransum terhadap kadar lemak karkas babi. Jurnal Ilmu Ternak 7 (2): 95-100.

Budaarsa, K. 2012. Babi Guling Bali Dari Beternak, Kuliner, Hingga Sesaji. Denpasar. Buku Arti.

Budaarsa, K., A.W. Puger, dan I.M. Suasta. 2016. Ekplorasi komposisi pakan tradisional babi bali. Majalah Ilmiah Peternakan Vol 19 (1): 6-11.

Barnes, D. M., C. C. Calvert and K. C. Klasing. 1995. Methionin deseciences protein and system but not rna acylation in muscles of chick. Jurnal Nutrition. 125: $2623-2630$.

Cheeke, P. R. 2005. Applied Animal Nutrition Feed and Feeding. 3rd Edition. Pearson Education, Inc., New Jersey.

Djagra, I. B. 2001. Ilmu Tilik Ternak Babi. Buku Ajar.Laboratorium Ternak Potong dan Kerja. Universitas Udayana. Denpasar.

NRC. 2012. Nutrient Requirements of Swine. $10^{\text {th }}$ Ed. Rev. United State Dept. of Agriculture, USA. 
Pierpoali, W., W Regelson, and C. Colman 1995. The Melatonin Miracle. Dabars Publisheers, New York.

Prawirokusumo, S., Nasrudin dan Umiyeni. 1987. Suplementasi methionin pada ransum ayam pedaging berkadar cassava tinggi. Proc. Seminar Penelitian Peternakan. Fakultas Peternakan. Universitas Gajah Mada, Yogyakarta.

Sampurna, I.P., I.K Saka, I.G.L. Oka, and P. Sentana. 2013. Biplot Simulation of Exponential Function to Determine Body Dimensions' Growth Rate of Bali Calf. Canadian Journal on Computing in Mathematics Natural Sciences Engineering and Medicine. Vol. 4. No 1 Th. $2013: 22-28$

Santosa. U. 1991. Tatalaksana Pemeliharaan Ternak Sapi. Penebar Swadaya. Jakarta.

Setiawan I. M, I.N. T. Ariana, dan I G.Suranjaya. 2014. Respon penambahan sekam padi pada ransum mengandung limbah hotel terhadap dimensi tubuh babi landrace persilangan. Majalah Ilmiah Peternakan Vol. 2 No. 1 Th. 2014 : 112-120

Soeparno. 2009. Ilmu dan Teknologi Daging. Yogyakarta : Gajah Mada University Press, Yogyakarta.

Sigit, N. 1995. Penggunaan Zeolit Beramonium dan Analog Hidroksi Methionin dalam Ransum Sapi Perah Laktasi. Tesis. Program Pascasarjana. Institut Pertanian Bogor, Bogor.

Siregar, B. 1994. Ramsum Ternak Ruminansia. Penebar Swadaya, Jakarta.

Sulastri, N. N., I K. Sumadi, dan I P. A. Astawa. 2018 Pengaruh suplementasi campuran lisin, metionin dan kolin dalam ransum terhadap penampilan babi bali jantan. Majalah Ilmiah Peternakan Vol 6 (2) : 253-263

Sumadi, I. K., I. M. Suasta, I. P. Ariastawa dan A. W. Puger. 2016. Pengaruh ME/CP Ratio Ransum Terhadap Performans Babi Bali. Majalah Ilmiah Peternakan. Vol 19. Hal 77 79.

Sumadi I. K., I. M. Suasta, I. P. A. Astawa dan A. A. P. Wibawa. 2018. Pengaruh Penambahan Campuran Asam Amino Esensial dan Kolin (Aminovit) dalam Pakan Tradisional pada Babi Bali Jantan. Majalah Ilmiah Peternakan Vol 21 (1) : 32-36

Sundari, L., C. M. C. M. Srilestari dan H. I. Wahyuni, 2004. Komposisi Lemak Tubuh Kelinci yang Mendapatkan Pakan Pellet dengan Berbagai Aras Lisin. Seminar Nasional dan Veteriner. Fakultas Peternakan. Universitas Diponogoro. Semarang.

Steel, R. G. D. and J. H. Torrie. 1991. Principle and Procedure of Statistics. McGraw Hill Book Co. Inc. New York.

Yuliyanti. 2018. Dimensi Tubuh Babi Bali Jantan Ynag di Berikan Ransum Dengan Suplementasi Lisin, Metionin, Dan Kolin. Skripsi. Fakultas Peternakan Universitas Udayana, Denpasar. 